\title{
İstemli Egzersizin Sıçanlarda Fruktozdan Zengin Beslenmeyle Uyarılan Böbrek Fonksiyon Bozukluğu ve Oksidan Durumu Düzeltici Etkisi
}

\author{
Oktay KAYA ${ }^{1}$, Deniz ERÇETIN ${ }^{2}$, Muhammed Ali AYDIN ${ }^{1}$, Melike SAPMAZ METIN \\ 1 Trakya Üniversitesi Tıp Fakültesi, Fizyoloji Anabilim Dalı, Edirne. \\ 2 Trakya Üniversitesi Tıp Fakültesi, Histoloji ve Embriyoloji Anabilim Dalı, Edirne.
}

\section{ÖZET}

Fruktoz tüketimindeki artışın oksidatif stresi artırarak böbrek fonksiyonlarını olumsuz etkilediği bilinmektedir. Egzersizin böbrek için koruyucu etkileri olduğu gösterilmiş olmasına karşın fruktozdan zengin beslenmeye bağlı değişimlerde istemli koşu egzersizinin etkileri bilinmemektedir. Çalışmamızda yüksek fruktozla beslenmenin böbrek fonksiyonu ve histolojisi üzerine meydana getirdiği olası etkiler ve oksidatif hasarda istemli fiziksel aktivitenin rolünü araştırdık. Deneyde kullanılan 21 adet erkek Sprague Dawley sıçan 3 gruba ayrıldı. Sekiz hafta süren deney boyunca Sedanter+su (kontrol) grubu içme suyu alırken sedanter+fruktozlu su (F) ve aktivite+fruktozlu su (A+F) grupları \%20 fruktoz içeren içme suyu aldılar. A+F grubu 8 hafta boyunca dönen tekerlek bulunan kafes yardımıyla istemli fiziksel aktivite yaptı. Deney sonunda alınan kan örneklerinde üre ve kreatinin seviyeleri, böbrek dokularında malondialdehit ve glutatyon düzeyleri incelendi. Ayrıca böbrek dokusunun histopatolojik incelemesi yapıldı. Böbrek fonksiyonlarının göstergesi olan serum kreatinin seviyesi F grubunda kontrol grubuna göre yüksek bulundu $(\mathrm{p}=0,012)$. Malondialdehit (MDA) seviyesi $\mathrm{F}$ grubunda kontrol grubuna göre yüksek iken $\mathrm{A}+\mathrm{F}$ grubunda kontrol grubuyla benzerdi (sırasıyla $\mathrm{p}=0,024 \mathrm{ve} p>0,99$ ). Glutatyon $(\mathrm{GSH})$ seviyesi $\mathrm{F}$ ve $\mathrm{A}+\mathrm{F}$ gruplarında kontrol grubuna göre yüksekti (sırasiyla $p=0,015$ ve $p=0,001)$. GSH seviyesi $A+F$ grubunda $F$ grubuna göre anlamlı düzeyde yüksekti $(p=0,014)$. Kontrol grubuna kıyasla $F$ grubunun böbrek kesitlerinde glomerüler çap, glomeruloskleroz oranı ve kollajen yoğunluğunda artış görüldü. $A+F$ grubunda kontrol grubuna benzer histolojik görünüm saptandı. Bu çalışma ile yüksek fruktozla beslenmeye bağlı böbrek yapısı ve fonksiyonlarında meydana gelen olumsuz etkilerin ve oksidatif hasarın istemli fiziksel aktivite ile önlenebileceği ortaya konmuştur.

Anahtar Kelimeler: İstemli egzersiz. Oksidatif stres. Böbrek fonksiyonları. Yüksek fruktozlu diyet.

Improving Effect of Voluntary Exercise on High Fructose Diet İnduced Kidney Dysfunction and Oxidant Status in Rats.

\begin{abstract}
It is known that the increase in fructose consumption negatively affects kidney functions by increasing oxidative stress. Although exercise has been shown to have protective effects for the kidney, the effects of voluntary jogging exercise on changes due to fructose-rich diet are unknown. In our study, we investigated the possible effects of high fructose feeding on kidney function and histology and the role of voluntary physical activity in oxidative damage. The 21 male Sprague Dawley rats used in the experiment were divided into 3 groups. During the experiment, which lasted eight weeks, the sedentary + water (control) group received drinking water, while the sedentary + fructose water (F) and activity + fructose water (A + F) groups received drinking water containing $20 \%$ fructose. The A + F group performed voluntary physical activity for 8 weeks with the help of a cage with a rotating wheel. Urea and creatinine levels in blood samples taken at the end of the experiment, malondialdehyde and glutathione levels in kidney tissues were examined. In addition, histopathological examination of the kidney tissue was made. Serum creatinine level, which is an indicator of renal functions, was found to be higher in the F group compared to the control group ( $\mathrm{p}=0.012)$. While the malondialdehyde (MDA) level was higher in the F group compared to the control group, it was similar to the control group in the A + F group ( $p=0.024$ and $p>0.99$, respectively). Glutathione (GSH) level was higher in F and A + F groups compared to the control group ( $\mathrm{p}=0.015$ and $\mathrm{p}=0.001$, respectively). GSH level was significantly higher in the $\mathrm{A}+\mathrm{F}$ group compared to the F group $(\mathrm{p}=0.014)$. Compared to the control group, an increase in glomerular diameter, glomerulosclerosis rate and collagen density were observed in the kidney sections of the F group. Histological appearance similar to the control group was detected in the A + F group. As a result of this study, it was revealed that the negative effects and oxidative damage on kidney structure and functions due to high fructose feeding can be prevented by voluntary physical activity.
\end{abstract}

Key Words: Voluntary exercise. Oxidative stress. Renal functions. High-fructose diet.

Geliş Tarihi: 29.Mart.2021

Kabul Tarihi: 14.Haziran.2021

Dr. Oktay KAYA

Trakya Üniversitesi Tıp Fakültesi

Fizyoloji Anabilim Dalı, Edirne, Türkiye

Tel.: 05056666440

E-posta: droktaykaya@gmail.com

Yazarların ORCID ID Bilgisi:

Oktay KAYA: 0000-0001-9639-8022

Deniz ERÇETIN: 0000-0001-9713-044X

Muhammed Ali AYDIN: 0000-0002-3741-4499

Melike SAPMAZ METIN: 0000-0001-9623-4116 
Kronik böbrek hastalığı $(\mathrm{KBH})$ yaygınlığı dünya genelinde \%8-16 olarak bildirilmekte, yıllık ekonomik bakım maliyeti yüksek olup 2011'de Amerika Birleşik Devletleri'ndeki toplam sağlık bakımı harcamalar1nın \%24'ünü oluşturmakta ayrıca KBH'nin son dönem böbrek yetmezliğine (SDBY) ilerlemesi bir halk sağl1ğ1 sorunu olarak görülmektedir ${ }^{1}$. Bu nedenle $\mathrm{KBH}$ açısından yeni biyobelirteçlerin belirlenmesi ve hastalığın ilk aşamalarında uygulanabilecek önleyici müdahalelerin ortaya konması bu ilerleme oranını azaltabilir.

Son yüzyılda fruktoz tüketimindeki artışa paralel olarak, obezite, diyabet ve böbrek hastalıklarının prevalansındaki artış, yüksek miktarda fruktoz tüketiminin böbrek hastalığı gelişiminde nedensel bir faktör olabileceği hipotezinin öne sürülmesine yol açmıştır². Düzenli olarak yüksek fruktozlu içecekler tüketen insanların, kronik böbrek hastalığı geliştirme riskinin $\sim \% 60$ arttığı bildirilmiştir ${ }^{3}$. Fruktoz, meyvelerde, sebzelerde ve balda bulunan bir monosakkarit olup günümüzde hazır gıda üretiminde yaygın olarak mısır şurubundan elde edilen fruktoz kullanılmaktadır. Fruktoz karaciğerde fruktoliz yoluyla metabolize edilir ve ekstrahepatik doku ve organların fonksiyonlarını bozma potansiyeline sahip glukoz, laktat, serbest yağ asidi (FFA), çok düşük yoğunluklu lipoprotein (VLDL) ve ürik asit (UA) gibi metabolitlere dönüşür ${ }^{2,4}$. Son zamanlarda fruktoz metabolizmasının (fruktoliz) mitokondriyal oksidatif strese, ürik asit gibi enflamatuar araciların üretimine ve fibrozise neden olarak $\mathrm{KBH}$ oluşmasında etkin rol oynadığı belirtilmektedir². Gersch ve arkadaşlarının çalışmasında \%60 fruktoz içeren diyet uygulamasının proteinüriyi alevlendirdiği, böbrek fonksiyonlarını kötüleştirdiği ve glomerülosklerozu hızlandırdığı ancak eşdeğer glukoz bazlı diyetle beslenen sıçanlarda bu bulguların gözlenmediği bildirilmiştir ${ }^{5}$. Ayrica, fruktozdan zengin diyetle beslenmenin preglomerüler vasküler hastalık gelişimi ile birlikte glomerüler hipertansiyon ve azalmış renal kan akışıyla sonuçlandığ $\breve{g}^{\text {da belirtilmektedir }}{ }^{6}$. Morfolojik değişimler açısından bakıldığında, yüksek fruktozlu bir diyetin böbrek ağırlığını arttırdığı ve normal sıçan böbreğinde hafif tubulointerstisyel hasara neden olduğu bildirilmiş; olası mekanizmanın proksimal tübüler hücre çoğalmasının fruktoz ile doğrudan uyarılması olabileceği düşünülmüştür ${ }^{7}$.

Egzersiz KBH oluşumunda koruyucu bir faktör olarak düşünülebilir. Egzersizin çeşitli böbrek hastalığı modellerinde glomerülosklerozu ve interstisyel fibrozisi azaltarak böbrek için koruyucu etkiler gösterdiği bildirilmiş ancak bu amaçla planlanan çalışmalarda genelde zorunlu şekilde yaptırılan koşu bandı ya da yüzme egzersiz modelleri kullanılmıştır ${ }^{8,9}$. Günümüzde modern yaşam koşulları düşünüldüğünde, kişiler tarafindan istemli yapılan fiziksel aktivitelerin giderek azalmış olduğu görülmektedir. Ancak gördüğümüz kadarıyla literatürde düzenli ve uzun süre yapılan istemli fiziksel aktivitenin yüksek fruktozlu diyet alan sıçanlarda böbrek fonksiyonları ve histopatolojisi üzerine etkileri incelenmemiştir. $\mathrm{Bu}$ çalışmanın amacı fruktozdan zengin beslenen sıçanlarda istemli fiziksel aktivitenin böbrek yapısı, fonksiyonları ve böbrek dokusunda oksidatif stresi önleyici olası koruyucu etkilerinin araştırılmasıdır.

\section{Gereç ve Yöntem}

Deneysel Dizayn: Bu çalışmada Sprague Dawley cinsi, 200-250 gr ağırlığında erkek sıçanlar kullanıldı. Tüm sıçanlar 12 saat aydınlık 12 saat karanlık döngüsünde, $21-22^{\circ} \mathrm{C}$ 'de barındırıldı ve 8 haftalık deneysel süreç boyunca ad libitum standart pellet yem ile beslendi. Siçanlar her grupta 7 hayvan olacak şekilde 3 gruba ayrıldı. Sedanter $+\mathrm{Su}$ (kontrol) Grubu: Bu gruptaki deneklere revers ozmoz sisteminden geçirilmiş içme suyu verildi. Sedanter + Fruktozlu Su (F) Grubu: Deneklere revers ozmoz sisteminden geçirilmiş ve \%20 fruktoz içeren içme suyu verildi ${ }^{10}$. Aktivite + Fruktozlu Su $(\mathrm{A}+\mathrm{F})$ : Deneklere revers ozmoz sisteminden geçirilmiş ve $\% 20$ fruktoz içeren içme suyu verildi ve denekler çalışma boyunca istemli fiziksel aktivite yaptı. F ve $\mathrm{A}+\mathrm{F}$ grubunda fruktozlu içme suyu günlük olarak taze hazırlandı. Bu çalışmanın öncesinde Hayvan Deneyleri Yerel Etik Kurulu'ndan izin alınmıştır.

Istemli fiziksel aktivite: Aktivite $(\mathrm{A}+\mathrm{F})$ grubundaki sıçanlar 8 haftalık deney süresi boyunca, istemli fiziksel aktivite yapabilmeleri için her kafeste tek siçan olacak şekilde dönen tekerlek bulunan kafeslerde tutuldu. Kafeslerdeki dönen tekerlek aparatının dönme Sıklığı bir kayıt düzeneği kullanılarak kaydedilerek her sıçanın fiziksel aktivite düzeyi belirlendi. Kafeslerde yer alan dönen tekerlek, daha önceki çalışmalara benzer şekilde $31,5 \mathrm{~cm}$ çapında ve $10 \mathrm{~cm}$ genişliğinde, tekerleğin kafes içi yüksekliği $7 \mathrm{~cm}$, tekerleğin çevresi ise 1,081 metredir $^{11}$. Günlük tekerlek devirleri saat yönü, saat yönünün tersi ve toplam tur sayısı olarak kayıt edilerek kat edilen mesafe $\mathrm{km}$ /gün olarak belirlendi. Uygulamaya başlamadan önce aktivite gruplarındaki tüm sıçanlara bir hafta boyunca dönen tekerlekli kafeslerde tekerleği tanımaları ve kullanabilmeleri için alıştırma yaptırıld $1^{12}$.

Doku-kan örneklerinin alınması ve analizler: Çalışmanın sonunda sıçanlara anestezi için ketamin (60 $\mathrm{mg} / \mathrm{kg}$ ) ve ksilazin (5 mg/kg) intraperitoneal uyguland1. Üre ve kreatinin ölçümü için sol ventrikülden kan alındı. Böbrekler uzunlamasına ikiye bölünerek böbreğin bir yarısı histopatolojik inceleme için \%10'luk formalin solüsyonuna konuldu, diğer yarısı malondialdehit (MDA) ve glutatyon (GSH) ölçümü için homojenize edildi ve analizler yapılıncaya kadar $80^{\circ} \mathrm{C}$ 'de saklandı. Lipid peroksidasyonunun son ürünü olan MDA'nın tiyobarbitürik asit (TBA) ile sıcak ve asit ortamda reaksiyona girmesi sonucu oluşan renk spektrofotometrik olarak ölçüldü ${ }^{13}$. Doku homojenatlarındaki serbest sülfidril (SH) gruplarının Ellman 


\section{Egzersiz ve Böbrek Fonksiyonları}

ayıracı ile oluşturduğu rengin spektrofotometrik olarak saptanması, GSH içeriğinin belirtilmesi için kullanıld $1^{14}$. Doku protein miktar tayini Lowry metoduna göre yap 1 ld $1{ }^{15}$.

\section{Histolojik Analizler}

Tüm gruplarda sıçanlardan alınan böbrek dokular1, \%10'luk tamponlu nötral formaldehit içerisinde fikse edildi. Yıkanan ve artan alkol serilerinden (\%70, \%90, \%96, \%100) geçirilen dokular parafine gömüldü. Oluşturulan böbrek dokusuna ait bloklardan 4-5 $\mu \mathrm{m}$ kalınlığında kesitler alındı, HematoksilenEosin (H+E), Periyodik asit-Schiff (PAS) + Hemalen (PAS+HL) ve Sirius Red ile boyand.

Böbrek kesitleri üzerinde yapılan tüm ölçümler ve skorlamalar iki araştırmacı tarafından kör olarak yapılmıştır.

$\mathrm{H}+\mathrm{E}$ ile boyanmış kesitlerin farklı büyütmelerde incelenmesi sonucunda, kontrol grubu böbrek dokularının genel histolojik özellikleri, deney ve aktivasyon grubunda ise fruktoza bağlı ortaya çıkabilecek histopatolojik değişiklikler incelendi.

Fruktoz kaynaklı değişimlerin değerlendirilmesi için, böbrek glomerüllerindeki PAS (+) materyalin artmasıyla karakterize olan glomerülosklerotik değişiklikler, her bir denekte, PAS+HL boyalı 2'şer kesitte toplam 100 glomerül üzerinde, X400 büyütmede incelendi ${ }^{16}$. Her glomerül için, glomerülosklerotik değişiklikler skleroz derecesi baz alınarak 0-4 arasında skorlandı. 0: normal glomerül, +:glomerülün $\leq \% 25$ 'ini oluşturan skleroz, ++: glomerülün $\leq \% 25-50$ 'sini oluşturan skleroz, +++ : glomerülün $\geq \% 50$ 'sini oluşturan skleroz, ++++: glomerülün tümünü kaplayan skleroz olarak derecelendirme yapıldı (Tablo I).

Kollajen lif yoğunluğu/fibrozis ise Sirius Red boyası ile gösterildi ve fotoğrafland1. Her grupta her bir deneğe ait Sirius Red boyalı 2 kesit üzerinde, korteks ve kortikomedullar alanlarda, peritübüler ve glomerüler interstisyumda, kırmızı boyanmış kollajen lif yoğunluğu X400 büyütmede semikantitaif olarak değerlendirildi. Medulla ve renal pelvis bölgeleri k1yasland1ğında, kontrol ile fruktoz diyeti uygulanan gruplar arasında fark izlenmediği için bu bölgeler değerlendirme dişı bırakıldı. +: normal, ++: orta, +++: yoğun, ++++: çok yoğun boyanma olarak kabul edildi (Tablo I).

\section{Morfometrik Analiz}

Morfometrik analiz için 4-5 $\mu \mathrm{m}$ kalınlığındaki böbrek kesitleri $\mathrm{H}+\mathrm{E}$ boyası ile boyandı. Her bir sıçan için, bir kesit üzerinde, kortikal ve kortikomedullar bölgelerde, rastgele 10 alanda izlenen toplam 30 glomerül, X200 büyütme altında değerlendirildi. Ölçümler iki araştırmacı tarafindan kör olarak yapıldı. Her glomerülün çapı, mikrometrik oküler kullanılarak 1şık mikroskobu (Olympus CX 31) altında ölçüldü. Seçilen her bir glomerülün en geniş ve en dar olmak üzere iki farklı çapı ölçüldü. Glomerüllerin ortalama çapları hesaplandı (Tarladacalisir ve ark. ${ }^{17}$ 'nın çalışmasından modifiye edilmiştir).

Istatistiksel Analiz: Analizler PASW statistic 2018 programı ile yapıldı. Verilerin normal dağılıma uygunluğu tek örneklem Kolmogorov Smirnov testi ile incelendi. Varyansların homojenliği Levene testi ile kontrol edildi. Gruplar arası karşılaştırmalarda tek yönlü varyans analizi (ANOVA) testi kullanıldı. Gruplar arasında farklılık bulunması halinde farklıl1ğın kaynaklandığı grupları belirlemek için Post Hoc Bonferroni çoklu karşılaştırma testi kullanıldı. Çalışmada $\mathrm{p}<0.05$ değerleri istatistiksel olarak anlamlı kabul edildi.

\section{Bulgular}

Bu çalışmada yer alan gruplara ait ortalama sıvı tüketimleri incelendiğinde, kontrol grubunda 56.90 \pm 4.10 $\mathrm{ml} /$ gün, $\mathrm{F}$ grubunda 64.51 $\pm 9.92 \mathrm{ml} /$ gün ve $\mathrm{A}+\mathrm{F}$ grubunda $78.07 \pm 11.14 \mathrm{ml} /$ gün olarak ölçülmüştür. $A+F$ grubunun günlük fiziksel aktivite düzeyinin ortalama $5055 \pm 1355 \mathrm{~m} /$ gün olduğu saptand.

\section{Böbrek Fonksiyon Belirteçleri:}

Serum üre, kreatinin seviyeleri şekil 1'de verilmiştir. Yüksek fruktoz alan gruplarda $(\mathrm{F}, \mathrm{A}+\mathrm{F})$ üre seviyeleri kontrol grubuna göre anlamlı düzeyde düşüktü (her ikisi için $\mathrm{p}=0.001$ ). Serum kreatinin seviyesi F grubunda kontrol grubuna göre anlamlı seviyede yüksek iken $\mathrm{A}+\mathrm{F}$ grubunda kontrol grubuyla benzerdi (sırasiyla $p=0,012$ ve $p=0,747)$.

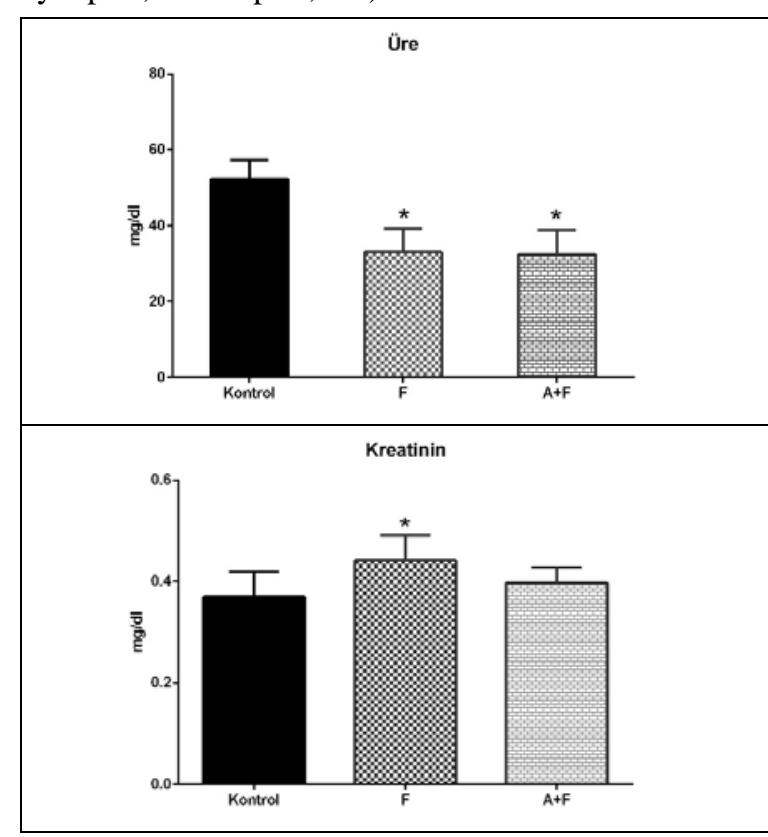

Şekil 1:

Deney gruplarına ait böbrek fonksiyon belirteçleri.

* kontrol grubuyla karşılaştırıldığında $p<0.05$ 


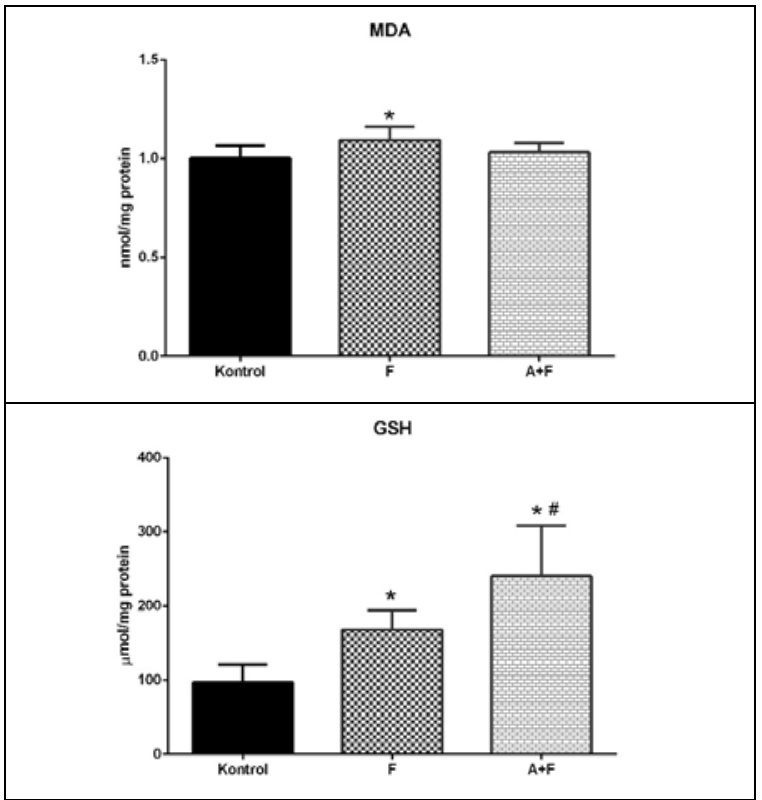

Şekil 2:

Deney gruplarına ait oksidatif stres belirteçleri. MDA: Malondialdehit, GSH: Glutatyon. * kontrol grubuyla karşılaştırıldı ğında $p<0.05$, \# F grubuyla karşılaştırıldı ̆̆ında $p<0.05$

\section{Histopatolojik Bulgular:}

Böbrek kesitleri $\mathrm{H}+\mathrm{E}$ ile boyanarak incelendiğinde, kontrol grubunda normal histolojik morfolojiye sahip Malpighi cisimciklerinin bulunduğu, proksimal ve distal tübüllerin yapısının normal olduğu görüldü (Şekil 3A). F grubunda glomerüler hipertrofi tespit edilirken (Şekil 3B), glomerüler ya da peritübüler inflamasyon izlenmedi. A+F grubunda ise glomerüler yapı kontrole yakın görünümdeydi (Şekil 3C). Böbrek kesitlerinde, korteks ve kortikomedullar alanlarda ortalama glomerül çapları kontrol grubunda 117,60 $\mu \mathrm{m}$, F grubunda $127,28 \mu \mathrm{m}$ ve $\mathrm{A}+\mathrm{F}$ grubunda $119 \mu \mathrm{m}$ olarak ölçüldü (Tablo I).

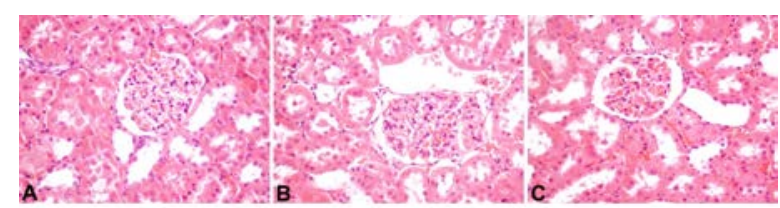

Şekil 3.

Deney gruplarına ait $H+E$ boyanmış kesitlerde mikroskopik bulgular. (A) Kontrol grubuna ait slçan böbrek dokusunda, kortekste glomerül ve Bowman boşluğunu içeren normal histolojik morfolojiye sahip Malpighi cisimciklerinin olduğu görülmektedir. Proksimal ve distal tübüllerin yapısı normal görünüm sergilemektedir. (B) F grubuna ait deneklerin böbrek dokusunda ise glomerül çaplarının arttı̆̆l, proksimal tübüller içinde yer yer hiyalin kalıntılar ve firçamsı kenar kayıplarl dikkati çekmektedir. (C) A+F grubunda, böbrek dokusunun histoloji olarak kontrol grubu deneklerine yakın yapı sergilediği görülmektedir. (A, $B, C ; X 400)$.
Tablo I. Deneklere ait histopatolojik değerlendirme skorlar1

\begin{tabular}{|lcccc|}
\hline $\begin{array}{l}\text { Histopatolojik } \\
\text { parametre }\end{array}$ & Kontrol $(n=7)$ & $F(n=7)$ & $A+F(n=7)$ & $P$ \\
\hline Glomerüler çap $(\mu \mathrm{m})$ & 117,60 & 127,28 & 119 & 0.03 \\
Glomerulosklerozis & + & +++ & ++ & \\
Interstisyel fibrozis & + & ++ & + & \\
\hline
\end{tabular}

Glomerüllerde, glomerülosklerozu yansıtan PAS (+) materyalin skoru Tablo I'de gösterilmiştir. Kontrol grubunun PAS boyalı böbrek kesitleri incelendiğinde, Malpighi cisimciklerinde, mor-menekşe renginde boyanan ve pariyetal yaprak hücrelerinin yerleştiği bazal membran ve glomerüler bazal membran yapıs1nın normal olduğu tespit edildi. Böbrek Malpighi cisimcilerinin çevresinde bulunan distal ve proksimal tübüllerin bazal membranları, proksimal tübül hücrelerinin apikal yüzeylerinde firçamsı kenar oluşturan PAS (+) mikrovilli yapısının normal görünümde olduğu tespit edildi (Şekil 4A). F grubuna ait deneklerin PAS ile boyalı böbrek dokusunda, pariyetal hücrelerinin yerleştiği bazal membranlar, glomerüler bazal membran (GBM) ve böbrek tübül hücrelerinin oturduğu bazal membranların kalınlığında artışın yanı sıra, glomerül içinde PAS (+) materyal miktarında da kontrol deneklerine kıyasla bir artış tespit edildi. Proksimal tübüllerde yer yer mikrovilli kaybı gözlendi (Şekil 4B). A $+F$ grubunun PAS ile boyalı böbrek dokusunda, pariyetal hücrelerinin yerleştiği bazal membranlar, GBM, böbrek tübül hücrelerinin oturduğu bazal membranlar ve proksimal tübüllerin mikrovilluslarının normale yakın yapı sergilediği, glomerül içi $\operatorname{PAS}(+)$ materyalin ise $\mathrm{F}$ grubuna kıyasla azaldığı tespit edildi (Şekil 4C).

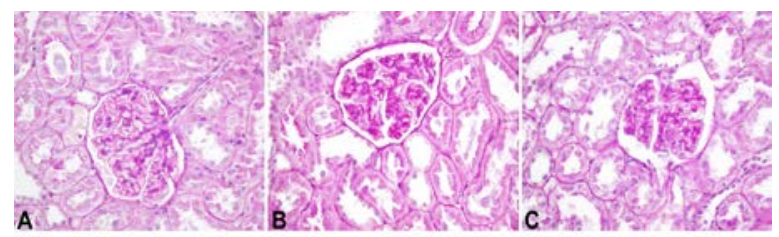

Şekil 4.

Deney gruplarına ait PAS $+H L$ boyanmış kesitlerde ışık mikroskopik bulgular. (A) Kontrol grubuna ait siçan böbrek dokusunun Malpighi cisimciklerinde,

Bowman kapsülünün pariyetal hücrelerinin yerleştiği bazal membran, glomerüler bazal membran (GBM), tübüler bazal membranlar ve proksimal tübüllerin mikrovilluslarının PAS (+) boyandığ , tüm bu yapılar normal histolojik görünüme sahiptir. (B) F grubuna ait deneklerin böbrek dokusunda, pariyetal hücrelerinin yerleştiği bazal membranlar, GBM ve tübüler bazal membranların kalınlığında artışla birlikte glomerül içi PAS(+) madde yoğunluğunda da artış gözlenmektedir. (C) A+F grubunda, bazal membranların kalınlığının ve PAS(+) madde yoğunluğunun F grubuna kıyasla azaldığ izlenmektedir. (A, B, C; X400). 


\section{Egzersiz ve Böbrek Fonksiyonları}

Çalışmamızda böbrek dokusunda kollajen lif birikimi Sirius red boyası ile değerlendirildi. Gruplara ait interstisyel dokuda kollajen yoğunluğu skoru Tablo I'de verilmiştir. Kontrol grubunun böbrek glomerüllerinin, tübüllerin ve damarların çevresini saran interstisyel doku yoğunluğunun normal oranda olduğu gözlendi (Şekil 5A-B). F grubuna ait deneklerin böbrek kesitlerinde ise, Sirius red ile kırmızı renkte boyanmış kollajen lif artışına bağlı olarak interstisyel dokuda kontrol grubuna göre artış olduğu tespit edildi (Şekil 5C-D). $\mathrm{A}+\mathrm{F}$ grubunun kesitleri incelendiğinde kollajen lif yoğunluğunun kontrol grubu deneklerinin böbrek dokularına benzer oranda olduğu tespit edildi (Şekil 5E-F).

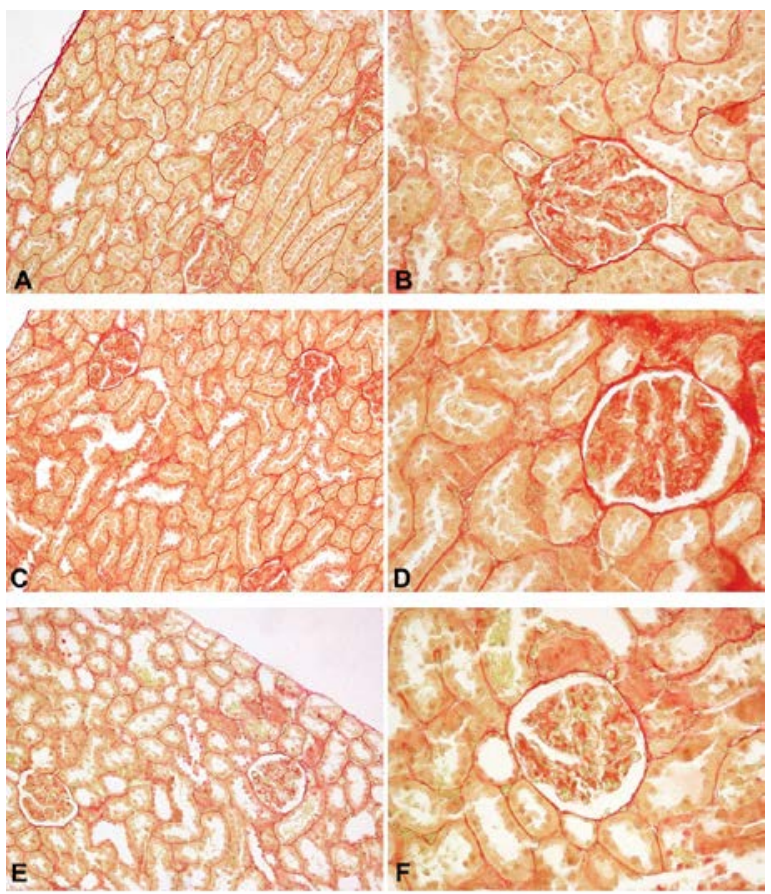

Şekil 5.

Deney gruplarına ait Sirius Red boyanmış kesitlerde ışık mikroskopik bulgular. (A, B) Kontrol grubuna ait sıçan böbrek dokusunda, glomerüler ve peritübüler interstisyumun normal yapıda olduğu görülmektedir. $(C, D) F$ grubuna ait böbrek kesitlerinde ise Sirius red ile kırmızı boyanan kollajen liflerin yoğunluğunda artış gözlenmektedir. (E, F) A+F grubunda kollajen lif yoğunluğunun $F$ grubuna klyasla azaldığ izlenmektedir. (A, C, E; X200. B, D, F; X400).

\section{Tartışma}

Bu çalışmada, yüksek fruktoz alımı oluşturulan deneysel modelde istemli fiziksel aktivitenin böbrek fonksiyonları, histopatolojisi, oksidatif ve antioksidatif belirteçler üzerine etkilerinin incelenmesi amaçlanmıştır. Elde edilen bulgular fruktozdan zengin beslenmenin böbreği yapısal ve işlevsel açıdan olumsuz etkileyebileceğini, fruktozdan zengin beslenmeye bağlı serum kreatinin düzeyinde, glomerül çapında ve böbrek dokusundaki oksidan parametrelerde artış oluştuğunu ancak istemli egzersiz yapılmasının işlevsel açıdan böbrek fonksiyonunun önemli bir belirteci olan kreatinin düzeyindeki artışı, oksidan bir faktör olan MDA düzeyini baskılamış olabileceğini ve antioksidan mekanizmaları aktive edebileceğini göstermektedir.

Böbrek fonksiyonunun önemli bir göstergesi serum kreatinin düzeyleridir. Çalışmamızda yüksek fruktozla beslenen sıçanlarda serum kreatinin seviyesi kontrol grubuna göre anlamlı düzeyde yüksekti. İstemli fiziksel aktivite grubunda kreatinin düzeyi fruktoz grubuna göre daha düşük bulunmakla birlikte istatistiksel olarak anlamlılık sınırına ulaşmadı. Bu bulgular fruktozla beslenmenin neden olacağı serum kreatinin yüksekliğinin egzersiz ile düşme eğilimine gireceği şeklinde yorumlandı. Çalışmamız yüksek fruktozla beslenmiş sıçanlarda istemli fiziksel aktivitenin etkilerinin araştırıldığı ilk çalışma olması nedeniyle bir ön çalışma olarak düşünülebilir. Bu konuda koşu bandı kullanılarak yaptırilan egzersizlerin fruktozdan zengin beslenmeye bağlı etkilerinin incelendiği çalışmalar bulunmaktadır. Hu ve arkadaşlarının ${ }^{8}$ yakın zamanda yüksek fruktozla beslenen siçanlarda 12 haftalık zorunlu koşu bandı egzersizinin etkilerini inceledikleri çalışmalarında, serum kreatinin seviyeleri kontrol ve yüksek fruktozla $(\% 60$ 'l1k) beslenen gruplarda benzer, yüksek fruktozla beslenip egzersiz yapan grupta ise her iki gruba göre daha düşük bulunmuştur. Çalışma sonuçlarımızdaki farklılık diyetteki fruktozun yüzdesinin $\mathrm{Hu}$ ve arkadaşlarının çalışmasında daha yüksek olmasından kaynaklanmış olabilir. Ayrıca Bizim 8 haftalık uygulamamıza karşın $\mathrm{Hu}$ ve arkadaşlarının modeli 12 hafta sürmüştür.

$\mathrm{Bu}$ çalışmada böbrek fonksiyonlarını değerlendirmek için kullandığımız bir diğer parametre olan serum üre düzeyi değerlendirildiğinde ise ilginç olarak yüksek fruktozla beslenen gruplarda serum üre düzeyleri kontrol grubuna göre anlamlı olarak düşüktü $(\mathrm{p}=0,001)$. Yüksek fruktozlu sıvı alan gruplarda üre düzeylerindeki bu düşüş su tüketiminin artmasına bağlı olarak oluşmuş olabilir. Çalışmada yer alan grupların ortalama sıv1 tüketimleri incelendiğinde kontrol grubunda $56.90 \pm 4.10 \mathrm{ml} /$ gün iken $\mathrm{F}$ ve $\mathrm{A}+\mathrm{F}$ gruplarında sirasıyla $64.51 \pm 9.92$ ve $78.07 \pm 11.14$ $\mathrm{ml}$ /gün olarak ölçülmüştür. $\mathrm{Bu}$ çalışma bulgularına göre fruktoz alan gruplarda sıvı tüketiminin daha fazla olması üre düzeyindeki azalmaya neden olan bir adaptasyon mekanizması olarak düşünülebilir.

Çalışmamızda, oksidatif hasarı belirlemek açısından böbrek dokularının MDA seviyeleri değerlendirildiğinde, yüksek fruktoz alan grupta MDA düzeyleri kontrol grubuna göre anlamlı olarak yüksek iken istemli fiziksel aktivite yapan grupta kontrol grubuyla benzerdi. Bu bulgu yüksek fruktozlu beslenmenin böbrek fonksiyonlarında meydana getirdiği bozulmada 
oksidatif stresin rolü olabileceği şeklinde yorumlanabilir. Malondialdehit (MDA) lipid peroksidasyonunun en önemli son ürünlerinden biridir ve yükselmesi serbest radikal üretiminin artışıyla ilişkilidir. Şener ve arkadaşlarının $^{18}$ sıçanlara 12 hafta \%10'luk fruktoz içeren içme suyu vererek metabolik sendrom modeli oluşturdukları çalışmalarında, yüksek fruktozlu diyet sonrası MDA seviyelerinde anlamlı olarak artış görülmüştür. Aynı çalışmada yüksek fruktozlu beslenmeyle beraber yüzme egzersizi yaptırılan hayvanların MDA seviyelerinin kontrol seviyeleriyle benzer olduğu görülmüştür. Yukarıdaki çalışmada yüzme egzersizine bağlı saptanan bulguların bizim bulgularımızla uyumlu olduğu dikkate alındığında böbrekte oksidan hasarın önlenmesinde egzersizin tipinin belirgin farklılık oluşturmadığı ve fiziksel aktif olmanın böbrek fonksiyonları açısından oksidatif hasarı önleyici etki oluşturarak düzeltici rol oynadığı görülmektedir.

Çalışmamızda ayrıca fruktozdan zengin beslenme ve istemli egzersize bağlı olası antioksidan özellikleri araştırmak amacıyla serumda GSH düzeylerindeki değişim incelenmiştir. Glutatyon (GSH) enzimatik olmayan bir antioksidandır. $\mathrm{Bu}$ çalışmada böbrek dokusu GSH seviyesi değerlendirildiğinde yüksek fruktozla beslenen gruplarda GSH düzeyi kontrol grubuna göre anlamlı olarak daha yüksekti. Ayrıca istemli fiziksel aktivite yapan grupta GSH seviyesi yüksek fruktoz alan gruba göre istatistiksel olarak anlamlı olarak yüksekti. Fruktozdan zengin beslenmenin GSH düzeyine etkileri tam olarak anlaşılabilmiş değildir ve bu konuda literatürde farklı bulgular yer almaktadır. Örneğin, Choi ve arkadaşlarının ${ }^{19}$ sıçanları 10 hafta \%65 fruktoz içeren yem ile besledikleri çalışmalarında GSH seviyesinin düştüğü gösterilmiştir. Çalışmamızda yüksek fruktozla beslenen grupta GSH seviyesinin yüksek olarak saptanması oksidan stresin etkilerini ortadan kaldırmak için uyarılmasına bağlı olabilir. Tipi ve yoğunluğundan bağımsız olarak egzersizin prooksidan göstergeleri düşürüp antioksidan kapasiteyi artırdığ 1 bilinmektedir ${ }^{20}$. Çalışmamızda da literatür bilgileriyle uyumlu olarak egzersiz yapan grupta sedanter olan gruplara göre GSH seviyesinin yüksek olduğu görülmüştür.

$\mathrm{Bu}$ çalışmada grupların $\mathrm{H}+\mathrm{E}$ boyalı kesitleri incelendiğinde kontrol grubuna kiyasla yüksek fruktozla beslenen sıçanların böbrek kesitlerinde, glomerüler hipertrofi nedeniyle glomerüler çap artışı görüldü. Glomerüler çap hipertrofinin bir göstergesidir. Kotyk ve arkadaşlarının çalışmasında, çalışmamızın sonuçlarıyla uyumlu olarak yüksek fruktozla beslenen sıçanlarda glomerüler çap kontrol grubuna göre anlamlı olarak yüksek bulunmuştur. İstemli fiziksel aktivite yapan grupta ise glomerül çapları kontrol grubuna benzerdi ${ }^{21}$. Bu bulgu istemli egzersizlerin glomerüler hipertrofiyi azaltıcı rol oynadığının bir göstergesi olarak düşünülebilir. Glomerüler hipertrofi mezangiyal hücre proliferasyonu, mezangiyal matriks artışı ve glomeruler inflamasyon kaynaklı olabileceği bildiril- miştir $^{16,22}$. Çalışmamızda yüksek fruktoz alan grubun PAS boyalı kesitlerinde kontrol grubuna göre artmış bazal membran kalınlaşması ve mikrovilli kaybı olduğu görülmüştür. Bunun yanı sıra fruktoz alan gruplarda, glomerül içinde $\mathrm{PAS}(+)$ madde yoğunluğunun artmasıyla karakterize glomerulosklerozis tespit edilmiştir. Bulgularımızı destekler şekilde, Gersch ve arkadaşlarının 6 hafta boyunca yüksek fruktozla besledikleri sıçanların PAS boyalı böbrek kesitlerinde de artmış glomerülosklerozu ve interstisyel hasarı gösteren bulgular rapor edilmiştir ${ }^{5}$. Bu konuda yakın zamanda yapılan çalışmalarda, 5 haftadan 8 haftaya kadar değişen süreçlerde fruktozdan zengin beslenmeye bağlı olarak böbrek kesitlerinde interstisyel kollajen liflerin $\operatorname{artış1}^{23}$ ya da kontrol grubuna göre daha yüksek glomerüler skleroz ve intrestisyel fibrozis olduğu gösterilmiştir ${ }^{24}$. Tüm bu bulgular fruktozdan zengin beslenmenin böbrekte fonksiyonel değişim yanı sıra yapısal hasara da neden olduğunu göstermektedir. Çalışmamızda Sirius red boyalı kesitler incelendiğinde ise yüksek fruktoz alan grupta kontrol grubuna göre artmış olan interstisyel kollajen lif yoğunluğu, istemli fiziksel aktivite yapan grupta kontrol grubuyla benzerdi. İstemli fiziksel aktivite yapan grupta kontrol grubuna benzer histolojik görünüm saptanması, fiziksel aktivitenin yapısal böbrek hasarından koruyucu bir etki oluşturması olarak yorumlanabilir.

Çalışmamızda bazı kısıtlılıklar bulunmaktadır. İlk olarak literatürde benzer gruplarda çalışmalar yapıldığı görüldüğünden, deneysel modelimizde normal içme suyu alan fiziksel aktivite grubu kullanılmadı. Böylece kullanılan deney hayvanı sayısı azaltılmış oldu. İkinci olarak çalışma modelimizde oksidatif stres ve antioksidan kapasitenin değerlendirilmesi için MDA ve GSH ölçümü yapıldı. Ek belirteçlerle daha detaylı olarak değerlendirilme yapılması mekanizmanın aydınlatılmasına katkıda bulunacaktır.

Tüm bu bulgular birlikte ele alındığında yüksek fruktozla beslenmenin böbrek fonksiyonları ve histolojisi üzerine olumsuz etkiler gösterdiğini ve bu etkilere oksidatif stresin katkısı olabileceğini düşündürmüştür. Çalışmamızın sonuçları istemli fiziksel aktivitenin yüksek fruktozla beslenmenin böbrek yapısı ve fonksiyonları üzerine olumsuz etkilerini oksidatif stresi azaltarak ve antioksidan etkiler oluşturarak önleyebileceğini ortaya koymuştur. $\mathrm{Bu}$ bulgular, böbreğin istemli fiziksel aktivite için önemli bir hedef organ olduğunu göstermekte ve fruktozdan zengin beslenmenin böbrekte oluşturduğu etkileri önleyici bir faktör olarak günlük fiziksel aktivitenin önemine işaret etmektedir.

Etik Kurul Onay Bilgisi:

Onaylayan Kurul: TRAKYA ÜNIVERSITESİ

Hayvan Deneyleri Yerel Etik Kurulu

Onay Tarihi: 28.08.2019

Karar No: E.358913 


\section{Egzersiz ve Böbrek Fonksiyonları}

Araştırmacı Katkı Beyanı:

Fikir ve tasarım: O.K., D.E., M.A.A., M.S.M.; Veri toplama ve işleme: O.K., D.E., M.A.A., M.S.M.; Analiz ve verilerin yorumlanması: O.K., D.E., M.A.A., M.S.M.; Makalenin önemli bölümlerinin yazılması: O.K., D.E., M.A.A., M.S.M.

Destek ve Teşekkür Beyanı:

Proje çalışmaları için destek alınmamıştır.

Çıkar Çatışması Beyanı:

Makale yazarının çıkar çatışması beyanı yoktur.

\section{Kaynaklar}

1. Zhong J, Yang HC, Fogo AB. A perspective on chronic kidney disease progression. Am J Physiol Renal Physiol. 2017: 1;312(3):F375-F384.

2. Nakagawa T, Johnson RJ, Andres-Hernando A, RoncalJimenez C, Sanchez-Lozada LG, Tolan DR, Lanaspa MA. Fructose Production and Metabolism in the Kidney. J Am Soc Nephrol. 2020 May;31(5):898-906. doi 10.1681/ASN.2019101015

3. Chapman CL, Grigoryan T, Vargas NT, Reed EL, Kueck PJ, Pietrafesa LD, Bloomfield AC, Johnson BD, Schlader ZJ. High-fructose corn syrup-sweetened soft drink consumption increases vascular resistance in the kidneys at rest and during sympathetic activation. Am J Physiol Renal Physiol. 2020 Apr 1;318(4):F1053-F1065

4. Zhang DM, Jiao RQ, Kong LD. High Dietary Fructose: Direct or Indirect Dangerous Factors Disturbing Tissue and Organ Functions. Nutrients. 2017 Mar 29;9(4):335.

5. Gersch MS, Mu W, Cirillo P, Reungjui S, Zhang L, Roncal C, Sautin YY, Johnson RJ, Nakagawa T. Fructose, but not dextrose, accelerates the progression of chronic kidney disease. Am J Physiol Renal Physiol. 2007 Oct;293(4):F1256-61.

6. Sánchez-Lozada LG, Tapia E, Bautista-García P, Soto V, Avila-Casado C, Vega-Campos IP, Nakagawa T, Zhao L, Franco M, Johnson RJ. Effects of febuxostat on metabolic and renal alterations in rats with fructose-induced metabolic syndrome. Am J Physiol Renal Physiol. 2008 Apr;294(4):F710-8.

7. Nakayama T, Kosugi T, Gersch M, Connor T, Sanchez-Lozada LG, Lanaspa MA, Roncal C, Perez-Pozo SE, Johnson RJ, Nakagawa T. Dietary fructose causes tubulointerstitial injury in the normal rat kidney. Am J Physiol Renal Physiol. 2010 Mar;298(3):F712-20.

8. Hu G, Xu L, Ma Y, Kohzuki M, Ito O. Chronic exercise provides renal-protective effects with upregulation of fatty acid oxidation in the kidney of high fructose-fed rats. Am J Physiol Renal Physiol. 2020 Mar 1;318(3):F826-F834.

9. Yoshida K, Kawamura T, Xu HL, Ji L, Mori N, Kohzuki M Effects of exercise training on glomerular structure in fructosefed spontaneously hypertensive rats. Hypertens Res. 2003 Nov;26(11):907-14. doi: 10.1291/hypres.26.907. PMID: 14714583.
10. Kim M, Do GY, Kim I. Activation of the renin-angiotensin system in high fructose-induced metabolic syndrome. Korean J Physiol Pharmacol. 2020 Jul 1;24(4):319-328.

11. Tayfur P., Palabiyik O., Uzun N., Sut N., Vardar S.A. Fruktozdan Zengin Beslenen Sıçanlarda İstemli Fiziksel Aktivitenin Metabolik ve Kardiyak İşlevlere Etkisi. Genel Tıp Dergisi 2019, 29, 2, 65-72. Doi:10.15321/GenelTipDer.2019253583. (Temmuz 2019)

12. Schultz RL, Kullman EL, Waters RP, Huang H, Kirwan JP, Gerdes AM, et al. Metabolic adaptations of skeletal muscle to voluntary wheel running exercise in hypertensive heart failure rats. Physiological research. 2013;62(4).

13. Ohkawa H, Ohishi N, Yagi K. Assay for lipid peroxides in animal tissues by thiobarbituric acid reaction. Anal Biochem. 1979 Jun;95(2):351-8.

14. Ellman GL. Tissue sulfhydryl groups. Arch Biochem Biophys. 1959 May;82(1):70-7.

15. Lowry Oh, Rosebrough $\mathrm{Nj}$, Farr Al, Randall Rj. Protein measurement with the Folin phenol reagent. J Biol Chem. 1951 Nov;193(1):265-75.

16. Seçkin İ, Uzunalan M, Pekpak MA, Köktürk S, Sönmez HA, Güngör ZB ve ark. Deneysel kronik nefroz modeli sıçan glomerüllerinde TGF- $\beta 1$ ekspresyonu ve mezangiyal değişiklikler. Cerrahpaşa Tıp Dergisi. 2019;43(1):6-12.

17. Tarladacalisir YT, Kanter M, Uygun M. Protective effects of vitamin $\mathrm{C}$ on cisplatin-induced renal damage: a light and electron microscopic study. Ren Fail. 2008;30(1):1-8.

18. Şener TE, Çevik Ö, Çetinel Ö, Şener G. Oxidative stress and urinary system damage in fructose-induced rat model of metabolic syndrome: Effect of calorie restriction and exercise. J Res Pharm. 2020; 24(3): 318-325.

19. Choi HN, Park YH, Kim JH, Kang MJ, Jeong SM, Kim HH, Kim JI. Renoprotective and antioxidant effects of Saururus chinensis Baill in rats fed a high-fructose diet. Nutr Res Pract. 2011 Aug;5(4):365-9.

20. de Sousa CV, Sales MM, Rosa TS, Lewis JE, de Andrade RV, Simões HG. The Antioxidant Effect of Exercise: A Systematic Review and Meta-Analysis. Sports Med. 2017 Feb;47(2):277293.

21. Kotyk T, Dey N, Ashour AS, Balas-Timar D, Chakraborty S, Ashour AS, Tavares JM. Measurement of glomerulus diameter and Bowman's space width of renal albino rats. Comput Methods Programs Biomed. 2016 Apr;126:143-53.

22. Rodriguez-Puyol D. The aging kidney. Kidney Int. 1998;54: 2247-2265.

23. Abdel-Kawi HS, Hassanin KM.A, Hashem KS. The effect of high dietary fructose on the kidney of adult albino rats and the role of curcumin supplementation: A biochemical and histological study. Beni-Suef University Journal of Basic and Applied Sciences. 2016;5:52-60.

24. Saleh R, Merghani BH, Awadin W. Effect of high fructose administration on histopathology of kidney, heart and aorta of rats. Journal of Advanced Veterinary and Animal Research. 2017 4(1);71-79. 
